\title{
Nutrients exportation by Tifdwarf bermudagrass from golf course greens
}

\author{
Caroline de Moura D’Andréa Mateus ${ }^{1^{*}}$ (1), Regina Maria Monteiro de Castilho² (D), Patrick Luan Ferreira dos Santos ${ }^{2}$ (D),

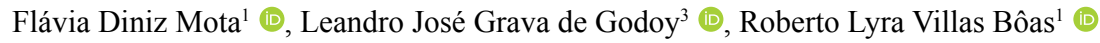

\author{
${ }^{1}$ Universidade Estadual Paulista - FCA/UNESP, Departamento de Ciência Florestal, Solos e Ambiente, Botucatu-SP, Brazil. \\ ${ }^{2}$ Universidade Estadual Paulista - FEIS/UNESP / Departamento de Fitotecnia, Tecnologia de Alimentos e Economia, Ilha Solteira-SP, Brazil. \\ ${ }^{3}$ Universidade Estadual Paulista - UNESP, Registro-SP, Brazil
}

\begin{abstract}
One of the management techniques used in greens (final areas of the holes) of golf course is the fertilizer. To correct fertilization program of these areas should know the consumption of nutrients throughout the plant cycle. The objective was to determine the export of nutrients by clipping of Tifdwarf bermudagrass (Cynodon dactylon (L.) Pers. x Cynodon transvaalensis Burtt-Davey) used in golf courses greens in the four weather seasons, as information to improve nutritional management. The research project was conducted in two golf courses in Sao Paulo State. Four greens were studied in each field, for a period of one year, using a $4 \times 2$ factorial (weather seasons $\mathrm{x}$ golf courses) in a completely randomized design. The production of dry matter and nutrient concentration were evaluated, and the absorption and exportation of nutrients by leaf clippings was subsequently calculated. The amount of nutrients exported by turfgrass clippings was different between the two golf courses. The summer was the season of greatest accumulation and export of nutrients in FG, except for Fe. Autumn was the season of greatest accumulation and export of nutrients in FCA, except for $\mathrm{Mn}$ and $\mathrm{Zn}$. Considering the amount of nutrients exported by the greens clippings of the Tifdwarf bermudagrass from the two golf courses studied, the macronutrients were exported in the following order: $\mathrm{N}>\mathrm{K}>\mathrm{Ca}>\mathrm{P}>\mathrm{S}>\mathrm{Mg}$ $\left(21.8,4.3,2.0,1.9,1.8,0.7 \mathrm{~g} \mathrm{~m}^{-2}\right)$ and the micronutrients were exported in the following order: $\mathrm{Fe}>\mathrm{Zn}>\mathrm{Mn}>\mathrm{Cu}>\mathrm{B}(257.8,27.4$, 23.6, 7.8, $6.0 \mathrm{mg} \mathrm{m}^{-2}$ ).
\end{abstract}

Keywords: Cynodon dactylon x Cynodon transvaalensis, mineral nutrition, nutrient absorption, sports field.

\section{Resumo}

Exportação de nutrientes pela grama bermuda tifdwarf de greens de campo de golfe

Uma das técnicas de manejo utilizada nos greens (áreas finais dos buracos) de campo de golfe é a adubação. Para correto programa de adubação destas áreas deve-se conhecer o consumo de nutrientes ao longo do ciclo da planta. Objetivou-se determinar a exportação de nutrientes pelas aparas de grama bermuda Tifdwarf (Cynodon dactylon (L.) Pers. x Cynodon transvaalensis Burtt-Davey) utilizada em greens de campo de golfe, nas quatro estações climáticas, como informação para melhorar o manejo nutricional realizado. O experimento foi realizado em dois campos de golfe no estado de São Paulo. Foram estudados quatro greens em cada campo, pelo período de um ano, sendo adotado um fatorial 4x2 (estações climáticas x campos de golfe) em delineamento inteiramente casualizado. Foram avaliadas a produção de massa seca foliar e a concentração de nutrientes, calculando-se posteriormente a absorção e exportação de nutrientes pelas aparas das folhas. A quantidade exportada de nutrientes pelas aparas de grama foi diferente entre os dois campos de golfe. O verão foi a estação de maior acúmulo e exportação de nutrientes no FG, exceto para Fe. O outono foi a estação de maior acúmulo e exportação de nutrientes no FCA, exceto para Mn e $\mathrm{Zn}$. Considerando a quantidade de nutrientes exportada pelas aparas da grama bermuda Tifdwarf dos greens nos dois campos de golfe estudados, os macronutrientes foram exportados na seguinte ordem: $\mathrm{N}>\mathrm{K}>\mathrm{Ca}>\mathrm{P}>\mathrm{S}>\mathrm{Mg}(21,8 ; 4,3 ; 2,0 ; 1,9 ; 1,8 ; 0,7 \mathrm{~g}$ $\mathrm{m}^{-2}$ ) e os micronutrientes foram exportados na seguinte ordem: $\mathrm{Fe}>\mathrm{Zn}>\mathrm{Mn}>\mathrm{Cu}>\mathrm{B}\left(257,8 ; 27,4 ; 23,6 ; 7,8 ; 6,0 \mathrm{mg} \mathrm{m}^{-2}\right)$.

Palavras-chave: Cynodon dactylon x Cynodon transvaalensis, gramado esportivo, marcha de absorção, nutrição mineral.

\footnotetext{
*Corresponding author: caroline_mateus@hotmail.com
} 


\section{Introduction}

Golf is the fastest growing sport in Brazil and in the world (Petrosillo et al., 2019). There are approximately 6 thousand golf courses in Europe, 17 thousand in the US and 40 thousand worldwide (Breibarth et al., 2018; Singh, 2017). In Brazil, golf has existed since the beginning of the $20^{\text {th }}$ century, and has 117 courses (Confederação Brasileira de Golfe, 2017). The contact with nature and physical activity are factors allied to the practice of golf and which has gained greater importance over time. In Brazil, the interest in golf increases substantially, and every year the number of fans of the sport has grown, as well as the number of courses built. In addition to the internal public, Brazil also has foreign players, as golf is a strong tourist attraction.

The golf courses are formed by natural grass and have between 60 and 80 hectares (Gillette et al., 2016). It can be said that it is a large agricultural area, however the main objective is not production, but obtaining quality, which is based on aesthetic, architectural, gameplay and maintenance aspects, all of which have an important participation in this regard.

The turfgrass used in golf courses are highly demanding in cultural treatments (Rice, Horgan and Hamlin, 2017), which requires a high degree of technification with the use of specific inputs and implements for each management operation carried out (Bock and Easton, 2020). Among the cultural practices are irrigation, fertilization, vertical and horizontal mowing, topdressing (covering with sand, with or without organic material), overseeding (sowing of winter grass) and pest and disease control.

Fertilization affects color, growth, yield and green up of warm season grasses, as bermudagrass (Serena et al., 2018). Bermudagrass is grown on athletic fields, because of its quality, excellent wear tolerance, and vigorous growth (Rice et al., 2019). Fertilization is an essential management practice to maintain the health and performance of greens (Throssell et al., 2017), where, e.g., a hybrid of bermudagrass with high nutritional requirements is used, and where daily mowing are made at certain times of the year, with the clippings removed from the site, an outflow of nutrients from the system.

Turfgrass have a nutritional requirement similar to other plants, requiring all macro $(\mathrm{N}, \mathrm{P}, \mathrm{K}, \mathrm{Ca}, \mathrm{Mg}$ and $\mathrm{S})$ and micronutrients ( $\mathrm{Fe}, \mathrm{Mn}, \mathrm{B}, \mathrm{Cu}, \mathrm{Zn}$ and $\mathrm{Mo}$ ) essential for their development (Christians et al., 2016). Leaf analysis, along with visual assessment of the turfgrass and soil analysis, can be used to diagnose nutritional problems and verify the efficiency of fertilizer programs, especially when it comes to micronutrient deficiency (McCarty, 2018). The leaf analysis in grass can be used to: confirm the suspicion of visual deficiency symptoms, verify toxicities, reveal the deficiency due to hidden hunger, evaluate the efficiency of the fertilizers applied, assist in the recommendation of fertilization and monitor the nutritional status of the plant during of the cycle. The use of content ranges to compare the values obtained, instead of a critical value, is preferred because the concentrations of nutrients vary throughout the year due to changes in the growth rate and reallocation of nutrients between parts of the turfgrass (Shaddox, 2017).

In addition to being used as a diagnostic tool, leaf analysis is used to obtain the amount of nutrients exported by the turfgrass. For a correct fertilization program on the turfgrass of golf course, one must know the nutrient consumption throughout the plant cycle in a situation of maximum quality, a characteristic intended for the game. The amounts of nutrients extracted by the crops are good information about your needs throughout the cycle. The daily rates of nutrient absorption are specific to each species and vary with the severity of mowing's and, especially, with the edaphoclimatic conditions (McCarty, 2018).

For the maintenance of turfgrass, the nutrient absorption curve must define the dose of application of a certain nutrient, avoiding a possible deficiency, luxury consumption (the plant absorbs more than it needs and that extra quantity has no impact on quality) or loss of nutrients if more than the amount required by the turfgrass is applied (Carrow et al., 2002).

Thus, the objective was to determine the export of nutrients by the clippings of Tifdwarf bermudagrass leaves used in golf course greens, as information to improve the nutritional management performed.

\section{Material and methods}

The research project was carried out in two golf courses located in the São Paulo State, one in Itupeva, SP $\left(23^{\circ} 03>44 \gg \mathrm{S}\right.$ and $\left.47^{\circ} 04>09 \gg \mathrm{W}\right)$ and another in Araras, SP $\left(22^{\circ} 23>17 \gg\right.$ S and $\left.47^{\circ} 17>55 » \mathrm{~W}\right)$, being called $\mathrm{FG}$ and FCA, respectively. The greens of each golf course were studied, constituted by Tifdwarf bermudagrass, which is an interspecific hybrid of Cynodon dactylon (L.) Pers. $\mathrm{x}$ Cynodon transvaalensis Burtt-Davey, coming from the USA, being the most used hybrid in greens areas of golf courses in Brazil (Reasor et al., 2018).

The greens were built according to the United States Golf Association (USGA, 2018), with $10 \mathrm{~cm}$ of gravel, a conventional drainage net in a "fishbone" format (sub-base) and $30 \mathrm{~cm}$ of substrate used as a base (mixture of sand with organic material), having an average of $550 \mathrm{~m}^{2}$ each. The organic material used in the construction of the greens in each course was different, using sugarcane filter cake in FG and commercial organic compost in FCA. The surface layer of the green, between 0 and $10 \mathrm{~cm}$, was studied, where the largest number of roots is concentrated, which was characterized before the execution of the experiment, through the determination of the chemical characteristics (Table 1).

In each of the golf courses, four individually assessed greens were studied every two weeks for a period of one year (July 2009 to June 2010), thus characterizing all seasons (Table 2). 
Table 1. Chemical soil analysis $(0-10 \mathrm{~cm})$ in the two golf courses (FG and FCA).

\begin{tabular}{|c|c|c|c|c|c|c|c|c|c|c|c|c|c|c|c|}
\hline & \multicolumn{15}{|c|}{ Chemical soil analysis $(0-10 \mathrm{~cm})$} \\
\hline & $\underset{\mathrm{CaCl}_{2}}{\mathrm{pH}-}$ & MO & $P$ resin & $\mathbf{H}+\mathbf{A l}$ & $\mathbf{K}$ & $\mathbf{C a}$ & Mg & SB & CTC & $\mathbf{V}$ & $\begin{array}{c}\text { B } \\
\text { Hws }\end{array}$ & $\begin{array}{c}\text { Cu } \\
\text { DTPA }\end{array}$ & $\begin{array}{c}\text { Fe } \\
\text { DTPA }\end{array}$ & $\begin{array}{c}\text { Mn } \\
\text { DTPA }\end{array}$ & $\begin{array}{c}\text { Zn } \\
\text { DTPA }\end{array}$ \\
\hline & & $\mathrm{g} \mathrm{dm}^{-3}$ & $\underset{\mathrm{dm}^{-3}}{\mathrm{mg}}$ & & & ...mn & $\mathrm{c} \mathrm{dm}$ & & & $\%$ & & &...$m g ~ d m$ & & \\
\hline FG & 6.3 & 8 & 31 & 9 & 1.2 & 10 & 4 & 16 & 25 & 62 & 0.12 & 0.5 & 48 & 1.1 & 1.8 \\
\hline FCA & 6.8 & 23 & 72 & 9 & 1.3 & 60 & 19 & 81 & 90 & 89 & 0.16 & 0.8 & 56 & 1.9 & 4.1 \\
\hline
\end{tabular}

Table 2. Average temperature $\left({ }^{\circ} \mathrm{C}\right)$ and precipitation + irrigation $(\mathrm{mm})$ in the weather seasons and annual average and total annual (July 2009 to June 2010) in the two golf courses (FG and FCA).

\begin{tabular}{|c|c|c|c|c|c|c|}
\hline & & \multicolumn{9}{|c|}{ Weather seasons (2009/2010) } \\
\hline & & Winter & Spring & Summer & Autumn & $\begin{array}{c}\text { Annual average and } \\
\text { annual total }\end{array}$ \\
\hline $\begin{array}{c}\text { Average temperature } \\
\left({ }^{\circ} \mathrm{C}\right)\end{array}$ & FG & 20.1 & 23.1 & 24.8 & 20.8 & 22.2 \\
\hline $\begin{array}{c}\text { Precipitation }+ \\
\text { irrigation (mm) }\end{array}$ & FCA & 20.9 & 24.2 & 25.4 & 21.8 & 23.0 \\
\hline
\end{tabular}

The experiment was in a $4 \times 2$ factorial scheme (weather seasons $x$ golf courses), in a completely randomized design with 4 replications (4 greens). Maintenance operations such as cutting, fertilizing (Table 3), irrigation, crop treatments and phytosanitary control were carried out normally, as is usual in each golf course studied (Table 4). The irrigation system used in the two golf courses is by spraying, with the use of retractable sprinklers.

Table 3. Total fertilizer applied on Tifdwarf bermudagrass over the course of a year in the two golf courses (FG and FCA).

\begin{tabular}{|c|c|c|c|c|c|c|c|c|c|c|c|}
\hline & \multicolumn{11}{|c|}{ Total fertilizer applied on bermudagrass over the course of a year } \\
\hline & $\mathrm{N}$ & $\mathrm{P}$ & $\mathrm{K}$ & $\mathrm{Ca}$ & $\mathrm{Mg}$ & $\mathrm{S}$ & B & $\mathrm{Cu}$ & $\mathrm{Fe}$ & $\mathrm{Mn}$ & $\mathrm{Zn}$ \\
\hline & \multicolumn{11}{|c|}{......kg ha ${ }^{-1}}$. \\
\hline FG & 355.7 & 58.2 & 424.8 & 318.0 & 115.0 & 66.6 & 0.02 & 0.02 & 4.75 & 0.04 & 0.07 \\
\hline FCA & 1019.1 & 112.3 & 229.6 & 600.4 & 211.5 & 451.5 & 0.07 & 0.09 & 1.06 & 1.00 & 2.70 \\
\hline
\end{tabular}

Table 4. Cultural treatments carried out on the golf courses FG and FCA in the weather seasons between July 2009 and June 2010

\begin{tabular}{|c|c|c|c|c|c|c|c|c|}
\hline \multirow{2}{*}{ Cultural treatments } & \multicolumn{2}{|c|}{ Winter } & \multicolumn{2}{|c|}{ Spring } & \multicolumn{2}{|c|}{ Summer } & \multicolumn{2}{|c|}{ Autumn } \\
\hline & FG & FCA & FG & FCA & FG & FCA & FG & FCA \\
\hline Mowing & 33 & 35 & 43 & 45 & 61 & 39 & 71 & 47 \\
\hline Grommer cutting & & 1 & 2 & & & & & \\
\hline Vertical cut & & 1 & 2 & 1 & 2 & 4 & 1 & \\
\hline Top dressing & & & 2 & 3 & 2 & 3 & & \\
\hline Scraping & & & & & & 1 & & \\
\hline Aeration & & & 1 & & & 1 & & \\
\hline Roll & & & & & 2 & & 6 & \\
\hline Double cut & & & & & & & 2 & \\
\hline Soil conditioner & 1 & & & & & & & \\
\hline
\end{tabular}


The clippings resulting from cutting the turfgrass on each green were collected every two weeks, starting on July 28 th, and ending on June 17th. The greens turfgrass was cut with a gasoline helical brush cutter with collector. After weighing the total fresh clippings from each green, a small sample was separated in a paper bag, weighed and dried in a forced air circulation oven for 72 hours at a temperature of $65{ }^{\circ} \mathrm{C}$, subsequently determining its dry matter and extrapolating up to the total area of the green (according to the fresh mass of the chips). The amount of total dry matter per $\mathrm{m}^{2}$ of each golf course was also determined, considering the number of cuts made in the period. Therefore, it was considered that between one sampling and another, the cuts generated the same dry matter.

The macronutrients and micronutrients concentration in the foliar blade were determined every two weeks in a sample of turfgrass clippings obtained in the area of each green, according to the modified methodology from Malavolta et al. (1997). The sampling of the bermudagrass clippings was carried out according to the recommendations of Shaddox (2017). The cutting height for sampling on greens was the one normally adopted in each golf course. After cutting and weighing the material, about 600 to $700 \mathrm{~mL}$ of clippings were removed and prepared for analysis. The preparation of the samples before being sent for analysis was also carried out according to the methodology of Shaddox (2017). Each sample was placed in a container about 20 $\mathrm{cm}$ in diameter and $10 \mathrm{~cm}$ high, containing distilled water in $3 / 4$ of its volume together with a weak soap solution (0.1$0.3 \%$ ); gentle agitation was carried out with a plastic rod and a pause of 30 seconds to allow the decanting of sand/ soil at the bottom of the container; afterwards, each sample was placed in a plastic sieve, rinsed with distilled water and placed on paper towels to remove excess moisture; then, the samples were placed in paper bags for drying in an oven at $65^{\circ} \mathrm{C}$. After drying, the leaf tissue was ground and analyzed to determine the concentration of nutrients.

With the biweekly data obtained from dry matter and concentration of nutrients in the foliar blade, the amount of nutrients exported by clipping of Tifdwarf bermudagrass of each green was obtained in the two golf courses studied. To observe the behavior throughout the year, biweekly data were gathered according to the four seasons.

The results were evaluated by analysis of variance and Tukey's test at the level of 5\% probability for comparison of averages using the statistical program "Statistix 10" for data analysis.

\section{Results and Discussion}

The turfgrass mass production in the summer increases with the beginning of spring due to the higher average temperature and the higher incidence of rain, in addition to the increase in the number of hours of light per day (photoperiod). With higher temperatures, more rain and light, turfgrass reach maximum growth in the middle of summer. At the end of summer and early autumn, with a drop in temperature, reduced precipitation and less availability of light, the growth rate is reduced until reaching very low values in winter (Godoy and Villas Bôas, 2008). The described behavior was verified in the two golf courses (Table 5).

Table 5. Dry matter of Tifdwarf bermudagrass clippings from greens and nitrogen fertilization applied in the two golf courses (FG and FCA) in the weather seasons.

\begin{tabular}{|c|c|c|c|c|}
\hline \multirow{4}{*}{ Weather seasons } & \multirow{2}{*}{\multicolumn{2}{|c|}{$\begin{array}{l}\text { Dry matter of bermudagrass clippings } \\
\qquad \text { g m m}^{-2} / \text { clipping }^{(1)}\end{array}$}} & \multirow{2}{*}{\multicolumn{2}{|c|}{$\begin{array}{l}\mathrm{N} \text { applied } \\
\mathrm{g} \mathrm{m} \mathbf{~}^{2}\end{array}$}} \\
\hline & & & & \\
\hline & \multicolumn{2}{|c|}{\begin{tabular}{|l|l|} 
Golf course \\
\end{tabular}} & \multirow[b]{2}{*}{ FG } & \multirow[b]{2}{*}{ FCA } \\
\hline & FG & FCA & & \\
\hline Winter & $1.78 \mathrm{bA}$ & $1.33 \mathrm{bA}$ & 5.00 & 11.56 \\
\hline Spring & $4.64 \mathrm{aA}$ & $1.83 \mathrm{bB}$ & 10.53 & 24.23 \\
\hline Summer & $4.35 \mathrm{aA}$ & $3.77 \mathrm{aA}$ & 5.10 & 28.32 \\
\hline Autumn & $2.35 \mathrm{bB}$ & $3.61 \mathrm{aA}$ & 14.94 & 37.80 \\
\hline CVC column & \multicolumn{2}{|c|}{1.19} & & \\
\hline CVC line & \multicolumn{2}{|c|}{0.89} & & \\
\hline $\mathrm{CV}(\%)$ & \multicolumn{2}{|c|}{20.69} & & \\
\hline F Weather seasons & \multicolumn{2}{|c|}{$23.227 * *$} & & \\
\hline F Golf course & \multicolumn{2}{|c|}{$8.896^{* *}$} & & \\
\hline F Weather seasons $x$ Golf course & \multicolumn{2}{|c|}{$14.790 * *$} & & \\
\hline
\end{tabular}


In spring and summer, the most aggressive cultural treatments are performed, such as vertical cutting and aeration, which may have influenced the values obtained. It is difficult to compare the mass produced and extracted from the bermudagrass greens clippings in Brazil with results obtained in other countries. Because in the period related to winter, countries that have this rigorous season use the sowing of winter turfgrass, a technique called overseeding, adding mass generated by the winter turfgrass to the small mass of the summer turfgrass.

In the FG golf course, there was a greater application of nitrogen fertilization in the autumn, which resulted in a greater number of dry clippings (Table 5). This management was adopted to prepare the turfgrass for more frequent and lower cuts, since at this time, three tournaments were held on this golf course and the objective was to increase the ball's rolling "speed". The management of fertilization, mainly nitrogen, is greatly altered due to the activities carried out on the golf course, which is why the fertilization recommendations in the foreign literature have such variable dosage values. In the FCA field, was observed the same behavior as FG, that is, a greater amount of dry matter of the clippings in the season that received more $\mathrm{N}$ (Table 5).

The variation in the leaves nutrients concentration can occur due to several factors: fertilization, export by clippings, plant growth, precipitation, possible negative interaction in the absorption of some nutrients and the presence of some nutrients (mainly micronutrients) in the applied chemical pesticides. Various nutrients, such as N, for example, showed a high concentration in the foliar blade in winter in the two golf courses (Table 6). This fact can be explained by the lesser growth of the plant in this season (due to less rainfall and less hours of light) that provides greater concentration of the nutrient in the foliar tissue.

Table 6. Macronutrients concentration of Tifdwarf bermudagrass leaves from the two golf courses greens (FG and FCA) in the weather seasons. annual average. and literature reference ranges.

\begin{tabular}{|c|c|c|c|c|c|c|c|c|c|c|c|c|}
\hline \multirow{4}{*}{ Weather seasons } & \multicolumn{2}{|c|}{$\mathbf{N}$} & \multicolumn{2}{|c|}{$\mathbf{P}$} & \multicolumn{2}{|c|}{$\mathbf{K}$} & \multicolumn{2}{|c|}{$\mathbf{C a}$} & \multicolumn{2}{|c|}{ Mg } & \multicolumn{2}{|c|}{$\mathbf{S}$} \\
\hline & \multicolumn{12}{|c|}{ 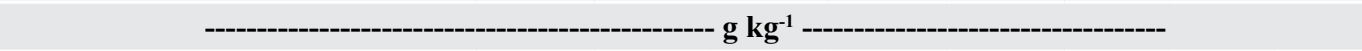 } \\
\hline & \multicolumn{12}{|c|}{ Golf course } \\
\hline & FG & FCA & FG & FCA & FG & FCA & FG & FCA & FG & FCA & FG & FCA \\
\hline Winter & $44 \mathrm{aB}$ & $49 \mathrm{aA}$ & $4.4 \mathrm{aA}$ & $2.4 \mathrm{bB}$ & $12 \mathrm{Aa}$ & $6 \mathrm{abB}$ & $3 \mathrm{bA}$ & $3 \mathrm{abA}$ & $1.5 \mathrm{aA}$ & $\begin{array}{l}1.2 \\
\mathrm{aB}\end{array}$ & $\begin{array}{l}3.6 \\
\mathrm{aA}\end{array}$ & $\begin{array}{l}3.1 \\
\mathrm{aB}\end{array}$ \\
\hline Spring & $41 \mathrm{abA}$ & $44 \mathrm{bA}$ & $3.7 \mathrm{bA}$ & $3.5 \mathrm{aA}$ & $6 \mathrm{bB}$ & $9 \mathrm{aA}$ & $3 \mathrm{abA}$ & $3 \mathrm{bA}$ & $\begin{array}{r}1.3 \\
b c A\end{array}$ & $\begin{array}{l}1.2 \\
\mathrm{aA}\end{array}$ & $\begin{array}{l}2.9 \\
\mathrm{bB}\end{array}$ & $\begin{array}{l}3.2 \\
\mathrm{aA}\end{array}$ \\
\hline Summer & $36 \mathrm{cA}$ & $38 \mathrm{cA}$ & $3.6 \mathrm{bA}$ & $2.6 \mathrm{bB}$ & $7 \mathrm{bA}$ & $8 \mathrm{bA}$ & $4 \mathrm{aA}$ & $3 \mathrm{bB}$ & $1.1 \mathrm{bB}$ & $\begin{array}{l}1.3 \\
\mathrm{aA}\end{array}$ & $\begin{array}{l}3.1 \\
b B\end{array}$ & $\begin{array}{l}3.4 \\
\mathrm{aA}\end{array}$ \\
\hline Autumn & $39 \mathrm{bcA}$ & $40 \mathrm{cA}$ & $\begin{array}{r}3.9 \\
a b A\end{array}$ & $\begin{array}{r}2.9 \\
\mathrm{abB}\end{array}$ & $10 \mathrm{aA}$ & $9 \mathrm{aA}$ & $3 \mathrm{abB}$ & $4 \mathrm{aA}$ & $1.1 \mathrm{cA}$ & $\begin{array}{l}1.2 \\
\mathrm{aA}\end{array}$ & $\begin{array}{l}3.6 \\
\mathrm{aA}\end{array}$ & $\begin{array}{l}3.2 \\
\mathrm{aB}\end{array}$ \\
\hline $\begin{array}{l}\text { FG and FCA (An- } \\
\text { nual average) }\end{array}$ & \multicolumn{2}{|c|}{41} & \multicolumn{2}{|c|}{3.4} & \multicolumn{2}{|c|}{9} & \multicolumn{2}{|c|}{3} & \multicolumn{2}{|c|}{1.3} & \multicolumn{2}{|c|}{3.3} \\
\hline $\begin{array}{l}\text { Reference ranges } \\
\text { McCarty (2018) }\end{array}$ & \multicolumn{2}{|c|}{$40-45$} & \multicolumn{2}{|c|}{$2.5-3.5$} & \multicolumn{2}{|c|}{$15-20$} & \multicolumn{2}{|c|}{$5-6$} & \multicolumn{2}{|c|}{$3.0-4.0$} & \multicolumn{2}{|c|}{$5.0-6.0$} \\
\hline CVC column & \multicolumn{2}{|c|}{3.71} & \multicolumn{2}{|c|}{0.59} & \multicolumn{2}{|c|}{2.61} & \multicolumn{2}{|c|}{0.82} & \multicolumn{2}{|c|}{0.18} & \multicolumn{2}{|c|}{0.46} \\
\hline CVC line & \multicolumn{2}{|c|}{2.77} & \multicolumn{2}{|c|}{0.44} & \multicolumn{2}{|c|}{1.95} & \multicolumn{2}{|c|}{0.61} & \multicolumn{2}{|c|}{0.14} & \multicolumn{2}{|c|}{0.34} \\
\hline CV $(\%)$ & \multicolumn{2}{|c|}{4.60} & \multicolumn{2}{|c|}{8.95} & 16 & & 12 & & 7.7 & & & \\
\hline F Weather seasons & 35.77 & $0 * *$ & 3.6 & & 3.3 & & 3.0 & & 6.714 & $4 * *$ & & \\
\hline F Golf course & 12.4 & $8 * *$ & 89.4 & $6 * *$ & 3.9 & & 0.17 & $6 n s$ & 2.67 & & & \\
\hline $\begin{array}{l}\text { F Weather seasons x } \\
\text { Golf course }\end{array}$ & 1.5 & & 11.5 & $3 * *$ & 15.2 & $7 * *$ & 7.70 & $6 * *$ & 9.000 & & 11. & $9 * *$ \\
\hline
\end{tabular}

Averages followed by the same lowercase letter in the column and uppercase in the row do not differ by the tukey test at $5 \%$ significance. ns- not significant; *- significant at $5 \%$ by the $\mathrm{F}$ test; ${ }^{* *}$ - significant at $1 \%$ by the $\mathrm{F}$ test. C.V.C. - Critical Value for Comparison. CV - Coefficient of Variation. 
The annual average concentration in the foliar blade for each nutrient, in the two golf courses, remained within the range considered sufficient, according to McCarty et al. (2018), for almost all the studied nutrients (Tables 6 and 7), as only $\mathrm{K}, \mathrm{Ca}$ and $\mathrm{Mg}$ showed slightly lower levels than adequate values. These cations are more easily lost by leaching, which happens more often on sandy substrates. Fe was the only nutrient that showed higher than enough values. The foliar concentration of $\mathrm{K}$ in turfgrass is only lower than that of N, as stated by Sartain (2002).

Table 7. Micronutrients concentration of Tifdwarf bermudagrass leaves from the two golf courses greens (FG and FCA) in the weather seasons. annual average. and literature reference ranges.

\begin{tabular}{|c|c|c|c|c|c|c|c|c|c|c|}
\hline \multirow{4}{*}{ Weather seasons } & \multicolumn{2}{|c|}{ B } & \multicolumn{2}{|c|}{$\mathrm{Cu}$} & \multicolumn{2}{|c|}{$\mathbf{F e}$} & \multicolumn{2}{|c|}{ Mn } & \multicolumn{2}{|c|}{ Zn } \\
\hline & \multicolumn{10}{|c|}{ - } \\
\hline & \multicolumn{10}{|c|}{ Golf course } \\
\hline & FG & FCA & FG & FCA & FG & FCA & FG & FCA & FG & FCA \\
\hline Winter & $9 \mathrm{bA}$ & $10 \mathrm{bA}$ & $18 \mathrm{aA}$ & $8 \mathrm{bA}$ & $671 \mathrm{bA}$ & $465 \mathrm{aA}$ & $34 \mathrm{bA}$ & $17 \mathrm{bA}$ & $35 \mathrm{aA}$ & $33 \mathrm{bA}$ \\
\hline Spring & $14 \mathrm{aA}$ & $14 \mathrm{aA}$ & $15 \mathrm{bA}$ & $11 \mathrm{aA}$ & $982 \mathrm{aA}$ & $215 \mathrm{aB}$ & $58 \mathrm{aA}$ & $40 \mathrm{bB}$ & $47 \mathrm{aA}$ & $39 \mathrm{bA}$ \\
\hline Summer & $9 \mathrm{bB}$ & $12 \mathrm{bA}$ & $16 \mathrm{abA}$ & $11 \mathrm{aA}$ & $288 \mathrm{cA}$ & $\begin{array}{l}263 \\
\mathrm{~A} \mathrm{a}\end{array}$ & $38 \mathrm{abB}$ & $91 \mathrm{aA}$ & $46 \mathrm{aB}$ & $134 \mathrm{aA}$ \\
\hline Autumn & $10 \mathrm{bA}$ & $10 \mathrm{bA}$ & $17 \mathrm{aA}$ & $11 \mathrm{aA}$ & $283 \mathrm{cA}$ & $234 \mathrm{aA}$ & $24 \mathrm{bA}$ & $37 \mathrm{bA}$ & $44 \mathrm{aA}$ & $45 \mathrm{bA}$ \\
\hline $\begin{array}{c}\text { FG and FCA } \\
\text { (Annual average) }\end{array}$ & \multicolumn{2}{|c|}{11} & \multicolumn{2}{|c|}{13} & \multicolumn{2}{|c|}{434} & \multicolumn{2}{|c|}{43} & \multicolumn{2}{|c|}{53} \\
\hline $\begin{array}{l}\text { Reference ranges McCarty } \\
\qquad(2018)\end{array}$ & \multicolumn{2}{|c|}{$15-20$} & \multicolumn{2}{|c|}{$10-20$} & \multicolumn{2}{|c|}{$30-400$} & \multicolumn{2}{|c|}{$80-100$} & \multicolumn{2}{|c|}{$40-80$} \\
\hline CVC column & \multicolumn{2}{|c|}{1.84} & \multicolumn{2}{|c|}{1.52} & \multicolumn{2}{|c|}{297.75} & \multicolumn{2}{|c|}{23.68} & \multicolumn{2}{|c|}{44.41} \\
\hline CVC line & \multicolumn{2}{|c|}{1.38} & \multicolumn{2}{|c|}{1.14} & \multicolumn{2}{|c|}{222.69} & \multicolumn{2}{|c|}{17.71} & \multicolumn{2}{|c|}{33.21} \\
\hline CV $(\%)$ & \multicolumn{2}{|c|}{8.46} & \multicolumn{2}{|c|}{5.85} & \multicolumn{2}{|c|}{35.88} & \multicolumn{2}{|c|}{28.56} & \multicolumn{2}{|c|}{42.82} \\
\hline F Weather seasons & \multicolumn{2}{|c|}{$3.488 * *$} & \multicolumn{2}{|c|}{$3.034^{*}$} & \multicolumn{2}{|c|}{$11.542 * *$} & 17.4 & $4 * *$ & 9.6 & $0 * *$ \\
\hline F Golf course & & & 518.6 & $5 * *$ & 23.60 & $6 * *$ & 3.0 & & & $61 *$ \\
\hline $\begin{array}{l}\text { F Weather seasons x Golf } \\
\text { course }\end{array}$ & & & 25.2 & 1** & 10.30 & $4 * *$ & 14. & $45^{*}$ & 8.3 & $7 * *$ \\
\hline
\end{tabular}

Averages followed by the same lowercase letter in the column and uppercase in the row do not differ by the tukey test at $5 \%$ significance. ns- not significant; *- significant at $5 \%$ by the $\mathrm{F}$ test; $* *$ - significant at $1 \%$ by the F test. C.V.C. - Critical Value for Comparison. CV - Coefficient of Variation

As the nutrients concentration in the foliar blade was similar between the golf courses studied, what determined the difference in the amount of nutrients absorbed and exported by the clippings of the bermudagrass leaves was the number of cuts made on the greens of each golf course and, consequently the amount of plant material exported in each cut (clippings). The total amount of nutrients absorbed and exported by the clippings was higher in the FG, which made the largest number of cuts (208) in relation to the 166 verified in the FCA. The number of cuts was influenced by the frequency of use of each golf course, being the higher frequency of use of a golf course results in greater wear, which requires greater handling.

The nutrients exported amount by bermudagrass clippings in the two golf courses varied between seasons (Tables 8 and 9) and may have been influenced not only by the number of cuts in each period, but also by the fertilization (Table 2) and precipitation (Table 3) that occurred throughout the year. The order of export of nutrients for the clippings of bermudagrass used in the greens of FG and FCA throughout the year was: $\mathrm{N}>\mathrm{K}>\mathrm{Ca}>\mathrm{P}>\mathrm{S}>\mathrm{Mg}>\mathrm{Fe}>\mathrm{Zn}>\mathrm{Mn}>\mathrm{Cu}>\mathrm{B}$ (Tables 8 and 9). 
Table 8. Amount of macronutrients exported by Tifdwarf bermudagrass clippings from two golf courses greens (FG and FCA) in the weather seasons and total annual.

\begin{tabular}{|c|c|c|c|c|c|c|c|c|c|c|c|c|}
\hline \multirow{5}{*}{ Weather seasons } & \multicolumn{12}{|c|}{ Amount of macronutrients exported by bermudagrass clippings } \\
\hline & \multicolumn{2}{|c|}{$\mathbf{N}$} & \multicolumn{2}{|c|}{$\mathbf{P}$} & \multicolumn{2}{|c|}{$\mathbf{K}$} & \multicolumn{2}{|c|}{$\mathbf{C a}$} & \multicolumn{2}{|c|}{ Mg } & \multicolumn{2}{|c|}{$\mathbf{S}$} \\
\hline & \multicolumn{12}{|c|}{ - } \\
\hline & \multicolumn{12}{|c|}{ Golf course } \\
\hline & FG & FCA & FG & FCA & FG & FCA & FG & FCA & FG & FCA & FG & FCA \\
\hline Winter & $\begin{array}{l}3.73 \\
\mathrm{bA}\end{array}$ & $\begin{array}{c}2.03 \\
\mathrm{bA}\end{array}$ & $\begin{array}{c}0.32 \\
\mathrm{cA}\end{array}$ & $\begin{array}{c}0.10 \\
\mathrm{bB}\end{array}$ & $\begin{array}{c}0.75 \\
\mathrm{cA}\end{array}$ & $\begin{array}{c}0.21 \\
\mathrm{bA}\end{array}$ & $\begin{array}{c}0.26 \\
\mathrm{cA}\end{array}$ & $\begin{array}{c}0.14 \\
\mathrm{bA}\end{array}$ & $\begin{array}{c}0.12 \\
\mathrm{bA}\end{array}$ & $\begin{array}{c}0.05 \\
\mathrm{bB}\end{array}$ & $\begin{array}{c}0.28 \\
\mathrm{cA}\end{array}$ & $\begin{array}{c}0.13 \\
\mathrm{bA}\end{array}$ \\
\hline Spring & $\begin{array}{l}6.42 \\
\mathrm{bA}\end{array}$ & $\begin{array}{c}3.70 \\
\mathrm{aB}\end{array}$ & $\begin{array}{l}0.55 \\
\mathrm{bcA}\end{array}$ & $\begin{array}{l}0.31 \\
\mathrm{abB}\end{array}$ & $\begin{array}{l}0.90 \\
\text { bcA }\end{array}$ & $\begin{array}{l}0.76 \\
\text { abA }\end{array}$ & $\begin{array}{c}0.60 \\
\mathrm{bA}\end{array}$ & $\begin{array}{l}0.24 \\
\mathrm{bB}\end{array}$ & $\begin{array}{c}0.22 \\
\mathrm{aA}\end{array}$ & $\begin{array}{l}0.11 \\
\mathrm{abB}\end{array}$ & $\begin{array}{l}0.46 \\
\text { bcA }\end{array}$ & $\begin{array}{l}0.30 \\
\text { abA }\end{array}$ \\
\hline Summer & $\begin{array}{c}9.88 \\
\mathrm{aA}\end{array}$ & $\begin{array}{c}4.93 \\
\mathrm{aB}\end{array}$ & $\begin{array}{c}0.99 \\
\mathrm{aA}\end{array}$ & $\begin{array}{l}0.35 \\
\mathrm{abB}\end{array}$ & $\begin{array}{c}2.01 \\
\mathrm{aA}\end{array}$ & $\begin{array}{c}1.00 \\
\mathrm{aB}\end{array}$ & $\begin{array}{c}1.04 \\
\mathrm{aA}\end{array}$ & $\begin{array}{c}0.40 \\
\mathrm{bB}\end{array}$ & $\begin{array}{c}0.29 \\
\mathrm{aA}\end{array}$ & $\begin{array}{c}0.17 \\
\mathrm{aB}\end{array}$ & $\begin{array}{c}0.84 \\
\mathrm{aA}\end{array}$ & $\begin{array}{c}0.44 \\
\mathrm{aB}\end{array}$ \\
\hline Autumn & $\begin{array}{l}6.43 \\
\mathrm{bA}\end{array}$ & $\begin{array}{c}6.40 \\
\mathrm{aA}\end{array}$ & $\begin{array}{c}0.63 \\
\mathrm{bA}\end{array}$ & $\begin{array}{c}0.48 \\
\mathrm{aA}\end{array}$ & $\begin{array}{l}1.57 \\
\mathrm{abA}\end{array}$ & $\begin{array}{l}1.33 \\
\mathrm{aA}\end{array}$ & $\begin{array}{l}0.55 \\
\text { bcA }\end{array}$ & $\begin{array}{c}0.72 \\
\mathrm{aA}\end{array}$ & $\begin{array}{l}0.20 \\
\text { abA }\end{array}$ & $\begin{array}{c}0.18 \\
\mathrm{aA}\end{array}$ & $\begin{array}{l}0.59 \\
\text { abA }\end{array}$ & $\begin{array}{c}0.51 \\
\mathrm{aA}\end{array}$ \\
\hline Total annual & 26.45 & 17.06 & 2.48 & 1.22 & 5.22 & 3.31 & 2.45 & 1.50 & 0.82 & 0.51 & 2.16 & 1.38 \\
\hline CVC column & \multicolumn{2}{|c|}{3.07} & \multicolumn{2}{|c|}{0.30} & \multicolumn{2}{|c|}{0.73} & \multicolumn{2}{|c|}{0.29} & \multicolumn{2}{|c|}{0.09} & \multicolumn{2}{|c|}{0.26} \\
\hline CVC line & \multicolumn{2}{|c|}{2.30} & \multicolumn{2}{|c|}{0.22} & \multicolumn{2}{|c|}{0.54} & \multicolumn{2}{|c|}{0.21} & \multicolumn{2}{|c|}{0.07} & \multicolumn{2}{|c|}{0.19} \\
\hline CV (\%) & \multicolumn{2}{|c|}{28.94} & \multicolumn{2}{|c|}{32.71} & \multicolumn{2}{|c|}{35.21} & \multicolumn{2}{|c|}{30.58} & \multicolumn{2}{|c|}{28.16} & \multicolumn{2}{|c|}{30.67} \\
\hline F Weather seasons & \multicolumn{2}{|c|}{$12.396^{* *}$} & \multicolumn{2}{|c|}{$13.672 * *$} & \multicolumn{2}{|c|}{$14.002 * *$} & \multicolumn{2}{|c|}{$19.127 * *$} & \multicolumn{2}{|c|}{$12.962 * *$} & \multicolumn{2}{|c|}{$16.159 * *$} \\
\hline F Golf course & \multicolumn{2}{|c|}{$17.805^{* *}$} & 34.5 & $2 * *$ & 13. & $0 * *$ & 20. & $6 * *$ & 22. & $7 * *$ & 16.4 & $0 * *$ \\
\hline $\begin{array}{l}\text { F Weather seasons } \\
\text { x Golf course }\end{array}$ & & & & & & & 10.2 & $8 * *$ & & & 2.2 & \\
\hline
\end{tabular}

Averages followed by the same lowercase letter in the column and uppercase in the row do not differ by the Tukey test at $5 \%$ significance. ns- not significant; *- significant at $5 \%$ by the $\mathrm{F}$ test; ${ }^{* *}$ - significant at $1 \%$ by the $\mathrm{F}$ test. C.V.C. - Critical Value for Comparison. CV - Coefficient of Variation.

Table 9. Amount of micronutrients exported by Tifdwarf bermudagrass clippings from two golf courses greens (FG and FCA) in the weather seasons and total annual.

\begin{tabular}{|c|c|c|c|c|c|c|c|c|c|c|}
\hline \multirow{5}{*}{$\begin{array}{l}\text { Weather } \\
\text { seasons }\end{array}$} & \multicolumn{10}{|c|}{ Amount of micronutrients exported by bermudagrass clippings } \\
\hline & \multicolumn{2}{|c|}{ B } & \multicolumn{2}{|c|}{$\mathrm{Cu}$} & \multicolumn{2}{|c|}{$\mathbf{F e}$} & \multicolumn{2}{|c|}{ Mn } & \multicolumn{2}{|c|}{ Zn } \\
\hline & \multicolumn{10}{|c|}{ 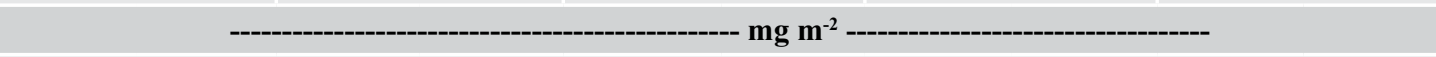 } \\
\hline & \multicolumn{10}{|c|}{ Golf course } \\
\hline & FG & FCA & FG & FCA & FG & FCA & FG & FCA & FG & FCA \\
\hline Winter & $0.72 \mathrm{cA}$ & $0.43 \mathrm{abA}$ & $1.37 \mathrm{cA}$ & $0.32 \mathrm{bB}$ & $38.71 \mathrm{bA}$ & $12.74 \mathrm{Aa}$ & $3.31 \mathrm{bA}$ & $0.76 \mathrm{bA}$ & $3.38 \mathrm{bA}$ & $1.41 \mathrm{cA}$ \\
\hline Spring & $2.37 \mathrm{abA}$ & $1.14 \mathrm{abB}$ & $2.59 \mathrm{bcA}$ & $0.95 \mathrm{abB}$ & $248.10 \mathrm{aA}$ & $19.21 \mathrm{aB}$ & $10.99 \mathrm{aA}$ & $3.55 \mathrm{abB}$ & $8.45 \mathrm{abA}$ & $3.38 \mathrm{bcB}$ \\
\hline Summer & $2.73 \mathrm{aA}$ & $1.38 \mathrm{aB}$ & $4.40 \mathrm{aA}$ & $1.40 \mathrm{abB}$ & $86.05 \mathrm{bA}$ & $26.81 \mathrm{aA}$ & $11.39 \mathrm{bA}$ & $7.02 \mathrm{aB}$ & $12.16 \mathrm{aA}$ & $12.61 \mathrm{aA}$ \\
\hline Autumn & $1.66 \mathrm{bA}$ & $1.58 \mathrm{aA}$ & $2.85 \mathrm{bA}$ & $1.72 \mathrm{aB}$ & $46.27 \mathrm{bA}$ & $37.76 \mathrm{aA}$ & $4.54 \mathrm{aA}$ & $5.67 \mathrm{aA}$ & $6.06 \mathrm{bA}$ & $7.27 \mathrm{abA}$ \\
\hline Total annual & 7.48 & 4.51 & 11.20 & 4.38 & 419.13 & 96.52 & 30.22 & 17.00 & 30.04 & 24.66 \\
\hline CVC column & \multicolumn{2}{|c|}{0.88} & \multicolumn{2}{|c|}{1.21} & \multicolumn{2}{|c|}{106.89} & \multicolumn{2}{|c|}{4.51} & \multicolumn{2}{|c|}{5.79} \\
\hline CVC line & \multicolumn{2}{|c|}{0.66} & \multicolumn{2}{|c|}{0.91} & \multicolumn{2}{|c|}{79.95} & \multicolumn{2}{|c|}{3.37} & \multicolumn{2}{|c|}{4.33} \\
\hline CV (\%) & \multicolumn{2}{|c|}{30.38} & \multicolumn{2}{|c|}{32.03} & \multicolumn{2}{|c|}{84.99} & \multicolumn{2}{|c|}{39.18} & \multicolumn{2}{|c|}{43.40} \\
\hline $\begin{array}{l}\text { F Weather } \\
\text { seasons }\end{array}$ & \multicolumn{2}{|c|}{$15.927^{* *}$} & \multicolumn{2}{|c|}{$15.527 * *$} & \multicolumn{2}{|c|}{$6.093 * *$} & \multicolumn{2}{|c|}{$14.123^{* *}$} & \multicolumn{2}{|c|}{$15.574^{* *}$} \\
\hline F Golf course & \multicolumn{2}{|c|}{$21.232 * *$} & \multicolumn{2}{|c|}{$59.825 * *$} & \multicolumn{2}{|c|}{$17.339 * *$} & \multicolumn{2}{|c|}{$16.353 * *$} & \multicolumn{2}{|c|}{$1.647^{\mathrm{ns}}$} \\
\hline $\begin{array}{c}\text { F Weather } \\
\text { seasons x } \\
\text { Golf course }\end{array}$ & \multicolumn{2}{|c|}{$4.013^{*}$} & \multicolumn{2}{|c|}{$4.217^{*}$} & 6.80 & & & & & \\
\hline
\end{tabular}

Averages followed by the same lowercase letter in the column and uppercase in the row do not differ by the Tukey test at $5 \%$ significance. ns- not significant; *- significant at $5 \%$ by the $\mathrm{F}$ test; ${ }^{* *}$ - significant at $1 \%$ by the $\mathrm{F}$ test. C.V.C. - Critical Value for Comparison. CV - Coefficient of Variation. 
The nutrients exportation in the period of one year for the clippings of the Tifdwarf bermudagrass leaves used in the greens was different between the two golf courses (Tables 8 and 9), as well as fertilization and the number of cuts made.

The annual $\mathrm{N}$ rates applied to golf course greens, formed with Ultradwarf bermudagrass, are generally between 390 to $880 \mathrm{~kg} \mathrm{~N}^{-1}$ (McCarty, 2018). In three Ultradwarf bermudagrass cultivars ('Tifeagle', 'Champion' and 'FloraDwarf') fertilization with $879 \mathrm{~kg} \mathrm{~N} \mathrm{ha}^{-1}$ year $^{-1}$ resulted in acceptable turfgrass quality (Park et al., 2017). To maintain a good quality of Tifway bermudagrass, at least 200 to $300 \mathrm{~kg} \mathrm{~N} \mathrm{ha}^{-1}$ per year is required in Georgia (Carrow et al., 2002). Sartain (2020) recommends doses of 400 to $900 \mathrm{~g} \mathrm{~N} \mathrm{~m}^{-2}$ per month for bermudagrass, in soil with a high sand content. Values suggested in the literature for nitrogen fertilization vary from 200 to $900 \mathrm{~kg} \mathrm{~N} \mathrm{ha}^{-1}$, determined by the hybrid of bermudagrass used, geographical location of the golf course, which determines the climatic conditions, and management practices adopted. In the golf courses studied, vastly different annual rates of $\mathrm{N}$ were applied: $355.7 \mathrm{~kg} \mathrm{ha}^{-1}$ in FG and $1019.1 \mathrm{~kg} \mathrm{ha}^{-1}$ in FCA (Table 2). On greens on US golf courses, are applied, an average of 158 to $182 \mathrm{~kg} \mathrm{ha}^{-1} \mathrm{~N}$ (Gelernter et al., 2016).

Although the amount of $\mathrm{N}$ applied in each field is quite different, the values of $\mathrm{N}$ concentration in the leaves of the two fields were close (Table 6). Possibly, in both golf courses the absorption of $\mathrm{N}$ was similar, thus, not all the $\mathrm{N}$ applied in the FCA was used, being much of which was lost through leaching, volatilization, denitrification, or immobilization. Typical total $\mathrm{N}$ and $\mathrm{P}$ losses, on average, from US golf courses, are 2 to $20 \mathrm{~kg}$ $\mathrm{ha}^{-1}$ year $^{-1}$ and 1.5 to $5 \mathrm{~kg} \mathrm{ha}^{-1}$ year ${ }^{-1}$, respectively (Bock and Easton, 2020).

The P importance for root growth is well known and turfgrass developed in P-deficient soils are unable to produce a well-developed root system (Christians et al., 2016). Thus, visible results of the application of $P$ occur during the establishment of new turfgrass (Sartain, 2020). The responses of turfgrass regarding the application of $\mathrm{P}$ depend on the content of $\mathrm{P}$ available in the soil, due to the fixation in iron and aluminum oxides, which makes it little mobile (Godoy and Villas Bôas, 2008). In already formed turfgrass, most studies have shown few responses even in soils with low P availability (Turgeon and Kaminski, 2019). However, in turfgrass implanted in very sandy soils, P deficiency can occur (Christians et al., 2016). Typically, 20 to $49 \mathrm{~kg} \mathrm{P} \mathrm{ha}^{-1}$ are required annually (McCarty, 2018). On greens on US golf courses, are applied, an average of 36 to $52 \mathrm{~kg} \mathrm{ha}^{-1} \mathrm{P}_{2} \mathrm{O}_{5}$ (Gelernter et al., 2016).

In turfgrass, resistance to cold and diseases, root growth, carbohydrate levels and generalized rusticity to adverse conditions have been related to potassium nutrition. The maximum leaf concentration of $\mathrm{K}$ in Tifway bermudagrass was obtained with the application of $900 \mathrm{~g} \mathrm{~K} \mathrm{~m}^{-2}$ every 90 days. Higher doses of fertilizer did not result in greater absorption, which suggests that bermudagrass does not accumulate excess $\mathrm{K}$, that is, there is no luxury absorption (Sartain, 2002).

In relation to $\mathrm{Ca}, \mathrm{Mg}$ and $\mathrm{K}$ cations, in order for the turfgrass to develop optimally, it is recommended that the following percentage should be present in the soil CTC: $65 \%$ to $85 \%$ of $\mathrm{Ca}, 6 \%$ to $12 \%$ of $\mathrm{Mg}$ and $2 \%$ to $5 \%$ of $\mathrm{K}$. However, some research has shown that the balance between the three cations is only important when one of the elements is deficient due to the excess of the other (Christians et al., 2016).

As the demand for sulfur in turfgrass is small, it is more difficult to have a deficiency of this nutrient. For this reason, applications of $\mathrm{S}$ do not produce great responses in the turfgrass green color unless it is in conditions of extreme deficiency (McCarty, 2018). As S is part of some amino acids, precursors of proteins, it also has an important role in the turfgrass growth (Christians et al., 2016).

Iron is the most important micronutrient for turfgrass, and the lack can damage the quality, causing uniform chlorosis in the new leaves (Singh, 2017). Because they are required in small quantities by the plant and because they are metals (except for B), inadequate applications of these elements can result in turfgrass toxicity (Godoy and Villas Bôas, 2008).

Knowing the right amount of nutrients required by the turfgrass throughout the year, it is possible to carry out fertilization more precisely, restoring nutrients without excess. In this way, the amount applied will be largely absorbed by the plant, thereby avoiding losses, nutritional imbalance, unnecessary expenses and environmental contamination problems.

\section{Conclusions}

Considering the amount of nutrients exported by the Tifdwarf bermudagrass clippings located on the greens in the two golf courses studied, the macronutrients were exported in the following order: $\mathrm{N}>\mathrm{K}>\mathrm{Ca}>\mathrm{P}>\mathrm{S}>\mathrm{Mg}(21.8$, $4.3,2.0,1.9,1.8,0.7 \mathrm{~g} \mathrm{~m}^{-2}$ ) and the micronutrients were exported in the following order: $\mathrm{Fe}>\mathrm{Zn}>\mathrm{Mn}>\mathrm{Cu}>\mathrm{B}$ (257.8, 27.4, 23.6, 7.8, $6.0 \mathrm{mg} \mathrm{m}^{-2}$ ).

\section{Author contribution}

CMDM: experiment idea, installation of the experiment, field analysis, data collection and analysis, interpretation, preparation and writing of the article, critical review. RMMC: adviser of work, analysis and interpretation of data, critical review of the article, approval of the final version of the article. PLFS: data collection and analysis, interpretation, critical review, translation. FDM: data collection and analysis, interpretation, critical review. LJGG: adviser of work, analysis and interpretation of data, critical review of the article. RLVB: adviser of work, analysis and interpretation of data, critical review of the article, approval of the final version of the article. 


\section{Acknowledgments}

The authors acknowledge the Brazilian agency FAPESP for support (process number 2008/58967-6).

\section{References}

BOCK, E.M.; EASTON, Z.M. Export of nitrogen and phosphorus from golf courses: A review. Journal of Environmental Management, v. 255, epub109817, 2020. DOI: https://doi.org/10.1016/j.jenvman.2019.109817

BREITBARTH, T.; KAISER-JOVY, S.; DICKSON, G. Global golf business and management: market issues and career prospects. In: BREITBARTH, T.; KAISER-JOVY, S.; DICKSON, G. (Eds.), Golf Business and Management: a global introduction. Abingdon: Routledge, 2018. p.3-19.

CARROW, R.N.; WADDINGTON, D.V.; RIEKE, P.E. Turfgrass soil fertility and chemical problems: assessment and management. Hoboken: John Wiley \& Sons, 2002. 412p.

CHRISTIANS, N.E.; PATTON, A.J.; LAW, Q.D. Fundamentals of turfgrass management. 5ed. New York: John Wiley \& Sons, 2016. 480p.

CONFEDERAÇÃO BRASILEIRA DE GOLFE. 2017. Golfe no Brasil. Available at: https:/www.cbg.com.br/ogolfe/golfe-no-brasil/. Accessed on June $11^{\text {th }} 2020$.

GELERNTER, W.D., STOWELL, L.J., JOHNSON, M.E.; BROWN, C.D. Documenting trends in nutrient use and conservation practices on US Golf Courses. Crop, Forage \& Turfgrass Management, v.2, p.1-10. 2016. DOI: https:// doi.org/10.2134/cftm2015.0225

GILLETTE, K.L.; QIAN, Y.; FOLLETT, R.F.; DEL GROSSO, S. Nitrous oxide emissions from a Golf Course Fairway and Rough after application of different nitrogen fertilizers. Journal of Environmental Quality, v.45, p.1788-1795, 2016. DOI: https://doi.org/10.2134/ jeq2016.02.0047

GODOY, L.J.G.; VILLAS BÔAS, R.L. Calagem e adubação para gramados: como potencializar a produção e a manutenção. In: VILLAS BÔAS, R.L; GODOY, L.J.G.; LIMA, C.P.; BACKES, C. Tópicos atuais em gramados. Botucatu: FEPAF, 2008. p.2-19.

MALAVOLTA, E.; VITTI, G.C.; OLIVEIRA, S.A. Avaliação do estado nutricional das plantas: princípios e aplicações. 2ed. Piracicaba: Potafos, 1997. 317p.

McCARTY, L.B. Golf turf management. Boca Raton: Taylor \& Francis, 2018. 760p.
PARK, D.M.; CISAR, J.L; FIDANZA, M.A.; NANGLE, E.J.; SNYDER, G.H.; WILLIAMS, K.E. Seasonal cultural management practices for aging Ultradwarf bermudagrass greens in the subtropics: I. Nitrogen and potassium fertilization. International Turfgrass Society Research Journal, v.13, n.1, 2017. DOI: https://doi.org/10.2134/ itsrj2016.05.0328

PETROSILlO, I.; VALENTE, D.; PASIMENI, M.R.; ARETANO, R.; SEMERARO, T.; ZURLINI, G. Can a golf course support biodiversity and ecosystem services? The landscape context matter. Landscape Ecology, v.34, p.2213-2228, 2019. DOI: https://doi.org/10.1007/s10980019-00885-w

REASOR, E.H.; BROSNAN, J.T.; STATON, M.E.; LANE, T.; TRIGIANO, R.N.; WADL, P.A.; CONNER, J.A.; SCHWARTZ, B.M. Genotypic and phenotypic evaluation of off-type grasses in hybrid Bermudagrass [Cynodon dactylon (L.) Pers. x C. transvaalensis Burtt-Davy] putting greens using genotyping-by-sequencing and morphological characterization. Hereditas, v.155, n.8., p.1-12, 2018. DOI: https://doi.org/10.1186/s41065-017-0043-3

RICE, P.J.; HORGAN, B.P.; HAMLIN, J.L., Evaluation of individual and combined management practices to reduce the off-site transport of pesticides from golf course turf, Science of The Total Environment, v.583, p.72-80, 2017. DOI: https://doi.org/10.1016/j.scitotenv.2017.01.001.

RICE, L.; BEASLEY, J.; GASTON, L.; SANDERS, K.; MUNSHAW, G. Planting rate and nitrogen fertility affect runoff losses during hybrid Bermudagrass establishment. Agrosystems, Geosciences \& Environment, v.2, p.1-5, 2019. DOI: https://doi.org/10.2134/age2019.07.0057

SARTAIN, J.B. Fertilize bermudagrass greens smartly and safely. 2020. Available at: <http://grounds-mag. com $/ \mathrm{mag} /$ grounds_maintenance_fertilize_bermudagrass greens/> Accessed on: Feb. 14 ${ }^{\text {th }}, 2020$.

SARTAIN, J.B. Tifway bermudagrass response to potassium fertilization. Crop Science, v.42, n.2, p.507512, 2002. DOI: https://doi.org/10.2135/cropsci2002.5070

SERENA, M.; SCHIAVON, M.; SALLENAVE, R.; LEINAUER, B. Nitrogen fertilization of warm season turfgrasses irrigated with saline water from varying irrigation systems. 1. Quality, spring green up and fall colour retention. Journal of Agronomy and Crop Science, v.204, p.252264, 2018. DOI: https://doi.org/10.1111/jac. 12254

SHADDOX, T.W. Tissue testing and interpretation for Florida turfgrasses. 2017. Available at: http://edis.ifas.ufl. edu/ep539. Accessed on: June 11 ${ }^{\text {th }}, 2020$. 
SINGH, B. Fundamentals of growing turfgrass. Chetpet, Chenai: Notion Press, 2017. 160p.

THROSSELL, C.; KRUSE, J.; BIGELOW, C.; MURPHY, J.A. Fertilizer granule collection and nutrient removal from putting greens following mowing. International Turfgrass Society Research Journal, v.13, p.275-279. DOI: https:// doi.org/10.2134/itsrj2016.05.0372
TURGEON, A.J.; KAMINSKI, J.E. Turfgrass Management. Pennsylvania: TurfPath, 2019. 400 p.

USGA. United States Golf Association. Building the USGA green: tips for success. 2018. Available at: <https://archive.lib.msu.edu/tic/usgamisc/monos/ tipsforsuccess-2018.pdf $>$ Accessed on: March $20^{\text {th }}, 2020$. 